\title{
BRIDGING CAUGHT IN A CROSSFIRE: THE MARKER OF SITUATED DEFINITENESS IN MANO AND LANGUAGE CONTACT
}

\author{
Maria Khachaturyan \\ University of Helsinki \\ maria.khachaturyan@helsinki.fi
}

\begin{abstract}
In this article, I review the basic semantic functions of the determiner $a$ in the South Mande language Mano, which is used to mark situated definiteness: most prominently, bridging and anaphora. The marker derives from the 3 sg pronoun. Similar markers are also used in a number of other South Mande languages, including Kla-Dan, Dan-Gweetaa, Guro, Tura and Gban. In Mano, as well as in the former four languages the head noun takes an optional low-tone head marking, which is more frequent in Mano than in other languages. I argue that the increased frequency of use of the marking is influenced by contact with the Southwest Mande language Kpelle, which has a grammaticalized preposed definiteness marker, also deriving from a 3sg prefix, and triggering low tone on the noun it attaches to.
\end{abstract}

Key words: Mande, language contact, definiteness, tonal morphology, linguistic area

\section{Introduction}

Mano is a South Mande language spoken in Guinea and Liberia. The Guinean varieties of Mano are in intense contact with the Southwest Mande language Kpelle (Khachaturyan \& Konoshenko in press), which results in contact effects in phonology, morphology, and lexicon (Khachaturyan 2018). This article focuses on a particular morphosyntactic phenomenon, the $3 \mathrm{sg}$ pronoun grammaticalized to be used for "situative definiteness" (Vydrin 2017a). It is used for first-time mentions when the context allows for reference retrieval via some associative relations (a function that is close to what Clark 1975 analyses in terms of 
bridging) but also for anaphora with referents mentioned in prior discourse.

A typical example of the use of the marker in question in Mano is the following.
(1) $\grave{a}$
$p \grave{\varepsilon}$
gó
yw⿳亠े
$\begin{array}{ll}\text { wáá } & y i ́ \\ \text { COP.NEG }>3 \mathrm{SG} & \text { in }\end{array}$
BRIDG thing:CSTR
spend
problem:CSTR
'You will not pay anything for this.' [MOC] ${ }^{1}$

Example (1) is taken from a story about a man who wanted to marry his daughter off. Instead of the traditional dowry, the groom-tobe had to harvest rice from his father-in-law-to-be's immense rice field. In (1), the father explains that he does not need the dowry, expected in the context of a marriage proposal, to be paid. The character uses the noun phrase à pè gó $y w \grave{\jmath}$ 'the-problem-of-spending-that-thing', where $p \bar{\varepsilon}$ 'thing' takes a low-tone form and is preceded by the marker $\grave{a}$. The marker is homonymous with the 3 sg non-subject pronoun $\grave{a}$.

A similar grammaticalization pattern of the 3 sg pronoun can be found in a number of South Mande languages, including Kla-Dan, Dan-Gweetaa, Tura, Guro and Gban. In all languages but Gban the marker has a distinct morphonological behavior: it optionally triggers the use of the low-tone form of the head noun. In Mano, the low-tone head marking is used more frequently than in other South Mande languages. I argue that this increased frequency could be due to a crossfire of genetic and areal factors. More specifically, in addition to being

${ }^{1}$ In the following discussion, the immediate discourse context is given in square brackets. The source of examples is indicated in the following way: [MOC] stands for Mano Oral Corpus (the corpus systematically used for the study contains about 3 hours of recordings of texts in various narrative genres and 40 minutes of conversations; additional examples are drawn from other recordings), [UBS] stands for the translation of the New Testament (UBS 1978), [notes] examples are taken from my field notes of spontaneously occurring speech and [el.] are elicited examples. The immediate discourse context is given in square brackets, and some supplementary information or free summary of the context is given in round brackets. 
genealogically close to other South Mande varieties, Mano could at the same time be influenced by Southwest Mande languages, and especially Kpelle, whose prenominal definite article obligatorily triggers low tone on the head and is homonymous with the 3sg basic (argument non-subject) pronominal marker.

The discussion is organized as follows. In §2 I introduce the basic semantics of the à marker in Mano and its difference from postnominal demonstratives of the language. In $\S 3$, I present the patterns of marking definiteness in other South Mande languages, paying close attention to the languages that employ a marker deriving from the $3 \mathrm{sg}$ pronoun, like Mano does. In $\S 4$, I introduce the Kpelle prenominal article and suggest a contact scenario. I discuss the findings in $\S 5$.

\section{Bridging marker in Mano}

The marker $\grave{a}$ in Mano is used for contextually defined referents. In some cases, these referents can be present at the interactive scene, but most frequently they are not. The semantic function of the à marker is best seen in comparison with postnominal demonstratives. Mano has six demonstratives, tój, dì̄a $, w \bar{\varepsilon}, y \bar{a}$, kilíw $\bar{\varepsilon}$, and kíliā. The former two are used only exophorically, for objects present at the interactive scene, the latter two are used only for anaphora, while the remaining two, $w \bar{\varepsilon}$ and $y \bar{a}$, are used for a variety of functions both endophoric (anaphora, discourse deixis, recognitional function) and exophoric (Khachaturyan 2020a).

In (2), the speaker invites the addressee to come take a bath, as she has heated the bathwater. The addressee was waiting to be invited, and the water, which may not be visible to her (if for example she is indoors and the water is outdoors) is a highly expected referent in this context. The high contextual saliency of the water (but not necessarily its prior mention) is marked by à.
(2) $n \bar{u}$
$w \bar{\varepsilon}$,
$\grave{a}$
yií
$\bar{a} a ̀$
kú
come DEM1 BRIDG water 3SG.PRF catch
'Come, come, the water is heated.' [notes + el.] 
Even when employed with referents present at the interactive scene, $\grave{a}$ is used when the interlocutors have some prior familiarity with the referent. In (3), the speaker addresses a toddler who has a knife near him. The speaker thinks that the child has taken the knife and so is perfectly aware of its position.
(3) ’̀
làà sí
bá
kpó magasin
wì
BRIDG knife take 2SG.SBJV $>3 \mathrm{SG}$ put storage[FR] under
'Take that knife and put it in the storage room.' [notes]

The referent in (3) is identifiable through its current spatial position, but especially through the interlocutors' (and specifically the addressee's) prior engagement with it. If the knife, an otherwise highly familiar object, happened to be near the child and presumably in his attention radar, but the child was not responsible for its whereabouts, the speaker would have used $w \bar{\varepsilon}$. Neither $w \bar{\varepsilon}$ nor $\grave{a}$ is obligatorily accompanied by a deictic gesture; the interlocutors are not necessarily physically copresent and seek to gaze at the same object. In contrast, if the child did not attend to the knife and was not aware of its position, his attention could be brought to it by using the exophoric demonstrative tój and a pointing gesture. So in contrast with demonstratives, à is used when the extralinguistic context alone, such as prior activities, suffices to identify the object.

It is not uncommon for the $\grave{a}$ marker to be used for marking anaphora, when the referent, not present at the discourse scene, was directly mentioned beforehand. In (4a), the speaker introduced the referent, the child, and in the immediately following utterance, (4b), he refers to him again by using the à marker.
(4) a. $\bar{o}$
$n \dot{\varepsilon}$
gহ̄zॄ
bè̄̄zè
$y \bar{e}$
3PL.PST child male first give.birth
'They had their first son.' 


\section{b. est-ce_que à néfú lèv́ gbāā siè isn't_it[FR] BRIDG child 3SG.NEG NEG spoil à_quatre_mois_comme_ça? \\ at_five_months_like_this[FR] \\ 'Didn't the child die at four months?' [MOC]}

The markers $w \bar{\varepsilon}, y \bar{a}$, kílíw $\bar{\varepsilon}$ and kílía are equally common in the anaphoric function. In the following sequence, the same referent is anaphorically referred to by using $w \bar{\varepsilon}$ in (5a) and $\grave{a}$ (which is incorporated in the portmanteau form of the auxiliary $m \bar{a})$ in (5b).

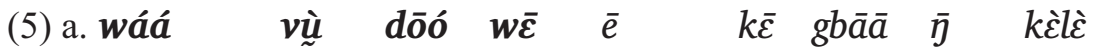 thousand ten one DEM1 3SG.PST be now $1 \mathrm{SG}$ hand máà gèè j́ diá gbāa
1SG.JNT>3SG say:JNT 1SG.SBJV pass:COND.COND now bùnój zàa
Bounouma in

'[Since I told her that I was going to Nzerekore, she said: "Give me a ride." I said, "Put one liter inside (my motorbike)." I had had ten thousand francs (the cost of one liter of gasoline) and I had said to myself that I would put in one liter and drive with it. I put one liter in the motorbike.] I had those ten thousand (francs) now, I said I would manage with it in Bounouma.'
b. $\boldsymbol{m} \bar{a}$
wáá
vì̀ dōó sí $m \bar{a}$
$d \grave{j} k \bar{\varepsilon}$
1SG.PST:BRIDG thousand ten one take $1 \mathrm{SG} . \mathrm{PST}>3 \mathrm{SG}$ give 'I took ten thousand (francs), I gave them.' [MOC]

In the selection of my oral corpus containing about 100 tokens of the à marker, about a half of them correspond to cases where the referents were directly mentioned in the prior discourse. Nine more are cases where the prior mention was made by using a different noun. A little less than a half of the examples, 39, however, are true first mentions. 
The referents introduced through these first mentions are usually connected to the referents introduced in the prior discourse by some trivial associative relationship, including culturally specific associations. In (6), for example, it is expected to be obvious for the interlocutors that lundi 'Monday' mentioned by the speaker is the day that immediately follows dimanche 'Sunday', which in turn follows samedi 'Saturday' in the speaker's account of his work and family routine. Both samedi and dimanche are used without the bridging marker.

\begin{tabular}{|c|c|c|c|c|}
\hline $\begin{array}{l}\ldots \grave{a} \\
\text { BRIDG }\end{array}$ & $\begin{array}{l}\text { lundi } \\
\text { Monday[FR] }\end{array}$ & $\begin{array}{l}y \bar{a} \\
\text { DEM2 }\end{array}$ & $\begin{array}{l}e ́ \\
\text { 3SG.SBJV }\end{array}$ & $\begin{array}{ll}\bar{\eta} & \text { s̀̀l } \bar{\jmath} \\
1 \mathrm{SG} & \text { obtaining }\end{array}$ \\
\hline $\begin{array}{l}6 \bar{o} \text {-á } \\
\text { impleme }\end{array}$ & & $\begin{array}{l}\text { zèe lé } \\
\text { here that }\end{array}$ & $\begin{array}{l}\bar{\eta} \\
1 \text { sG.EXI }\end{array}$ & $\begin{array}{l}\text { wòá } \\
\text { lay.GER.with }\end{array}$ \\
\hline $\begin{array}{l}k \hat{\varepsilon} \hat{\imath} \\
\text { room.LOC }\end{array}$ & $\begin{array}{l}\text { làāpíé } \\
\text { morning }\end{array}$ & $\begin{array}{l}\bar{a} . . . \\
\text { BKGR }\end{array}$ & & \\
\hline
\end{tabular}

'[When I go to Gouécké on Saturday, I come back and I sleep here on Sunday,] if Monday finds me here and I am lying down in my room in the morning, [I know that I will be asked to buy pens (for my children, who keep losing them)].' [MOC]

Similarly, in (7), the speaker (a character in a folk story) is organizing a belated funeral for his parents and announces that he has everything needed for the feast. The key components are expected to be known by the audience to be food items, as is the cooking oil, which is explicitly specified.
(7) $\begin{aligned} & \grave{a} \\ & \text { p }\end{aligned}$ BRIDG thing every 1SG.EXI come-INF $3 \mathrm{SG}$ with BRIDG nónó nì oil ASSOC

'I bring everything needed (for the ceremony), and even the oil.' [MOC] 
The term bridging was introduced by Clark (1975) in a discussion of reference resolution when a definite description is introduced without the referent being mentioned beforehand. Instead, the referent is unambiguously associated with another previously established referent (for a crosslinguistic discussion of the function, see Becker 2019). Typical types of associative relation, according to Clark, include part whole ('I looked into the room. The ceiling was high'), as well as necessary ('John was murdered yesterday. The murderer got away') and unnecessary roles in the event ('John died yesterday. The murderer got away' and 'John was murdered yesterday. The knife lay nearby'). As shown by examples (6) and (7), the marker à has bridging as one of its central functions. Moreover, while the anaphoric function is equally common for $\grave{a}$ and for several postnominal demonstratives in Mano, the bridging function is what distinguishes the à marker from the demonstratives, which is the reason I picked this function for the glossing abbreviation.

The marker $\grave{a}$ can be used in combination with the postnominal demonstratives $w \bar{\varepsilon}, y \bar{a}, k i l i ́ b \bar{\varepsilon}$ and kílía. About a third of all studied examples with $\grave{a}$ also contain a demonstrative. The combination of $\grave{a}$ with a demonstrative can be used both in cases of anaphora (8) and of first mentions (6).

(8) $\bar{e}$

Kónákrí lè séń

3SG.PST Conakry place every

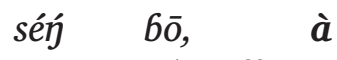

$\begin{array}{llllll}\text { nínà } & \bar{e} & \text { kílía } & \grave{a} & \text { bií } & l \bar{\varepsilon}\end{array}$

wicked.spirit 3SG.REFL ANAPH 3SG image 3SG.EXI

$\bar{\eta} \quad k \grave{c} l \grave{\varepsilon} \quad z e ̀ \bar{e}$

$1 \mathrm{SG}$ hand here

'It (the spirit) took over everywhere in Conakry, this evil spirit I have the picture with me here.' [MOC]

Except anaphora and bridging, the $\grave{a}$ marker is not used in other functions typical of definiteness markers, such as to mark contextually unique referents. Thus, (9a), with the bare noun bí 'night', is a typical 
way to say 'the night has come.' If the speaker adds the marker $\grave{a}$, as in (9b), it is to convey some relationship to the previous discourse context. For example, as my consultant explained, the marker would be used when one expects a person to come on a certain night, the night came but the person isn't there. For a discussion of the semantics of $\grave{a}$ in the context of typology of definiteness, see $\S 5$.

(9) a. bi $\underset{\sim}{a} a ̀ \quad m i ́$

night 3SG.PRF come

'The night has come.' [el.]

b. à

bí $\quad \bar{a} a ̀$

mí, lèc

gbāā nū

BRIDG night 3SG.PRF come 3SG.NEG NEG come

'That night came, he did not come.' [el.]

The marker à can be used with proper nouns (10) or in nonreferential contexts, such as negative contexts (11), which indicates that its function is not definiteness or referentiality per se, but rather marking the contextual retreivability of the referent. In (10), the speaker talks to her addressee about a mutual acquaintance, called Dinos. His name was relevant in the discussion of the number of sons different people have and about a traditional medicine that is supposed to make the woman conceive a boy.

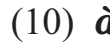
Dìnóò, ye,
nर́ ḡ̄̄z⿺̀ $\quad l \bar{a} \bar{a}$
kèlè pèèle
BRIDG Dinos 3SG.EMPH child male 3SG.EXI>3SG had two
'Dinos, as for him, he has two boys.' [MOC]

In (11), the narrator explains that the main character of the story managed to avoid a major pitfall and, although he was a renowned dancer, to refrain (with the help of his wife) from dancing to the sound of traditional musical instruments mentioned earlier one by one. 


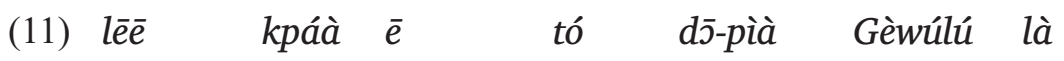 woman dry 3SG.PST leave stop-INF Gewulu on lècé gbā tá $k \bar{\varepsilon}$ à wèè dò mò kíli \\ 3SG.NEG NEG song do BRIDG speech:CSTR INDF on this.way \\ 'The old woman kept supporting him and he did not dance to a single (of those) sounds of music.' [MOC]}

In (12), the same discussion as in (10) continues, with several human referents introduced by the $a$ marker. Note that the marker is used with inalienably possessed nouns, immediately followed by a nonsubject pronoun, as in à $\bar{\eta}$ lòkóò 'that mother of mine'. While the à marker derives from the $3 \mathrm{sg}$ non-subject pronoun $\grave{a}$, the fact that it does not compete with other non-subject pronouns for the same slot shows that it has grammaticalized into a marker with a distinct grammatical function.

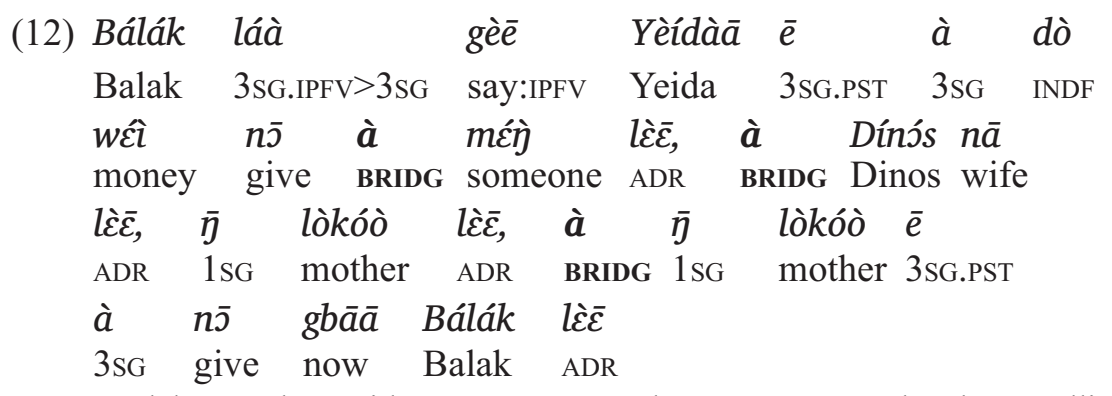

'Balak says that Yeida gave someone else's money to, whatchamacallit, to Dinos's wife, to my mother, my mother gave it to Balak.' [MOC]

The final, but not least crucial, property of the à marker is that the head noun it accompanies sometimes takes the low-tone form (1). The same form, which can be characterized as a construct form (Khachaturyan $2020 \mathrm{~b}),{ }^{2}$ is used in a variety of noun phrases with a preposed modifier,

${ }^{2}$ The term "construct forms" was coined by Creissels to designate a type of head marking which includes, but is not limited to, the construct state forms 
such as in (13), làkóle kà pupil house:CSTR, 'school'. Although the cases where the à determiner is used with a noun in the low-tone construct form are a minority, they still represent a considerable proportion (10 tokens with the low-tone form, 48 tokens with the lexical form, with the rest of the tokens it is not clear since either their lowtone form coincides with the lexical form or they are proper names or borrowings, which do not take a construct form). The rules which trigger the use of the low-tone form are not clear. The same applies to other syntactic contexts where the low-tone form is used, as there is significant variation. For instance, there are cases where the same noun is used in the low-tone form with a nominal modifier and in the lexical form with the à marker within the same sentence (13). There are also pairs of examples with the à marker used with lexical and low-tone forms of the same noun. Compare (11) above and (14) below, both including the noun wéè 'speech' in different forms. Other pairs attested involve the nouns $p \bar{\varepsilon}$ 'thing' and $y w s$ 'problem'.

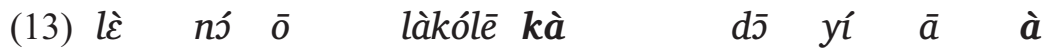
place just 3PL.PST pupil house:CSTR stop there BKGR BRIDG ká zì $\quad \bar{a}$

house old BKGR

'Where they built the school, the old building.' [MOC]

$\begin{array}{llllllll}a & \text { wéè } & \bar{e} & k i l i ́ a & \bar{e} & k \bar{\varepsilon} & \text { wálà sónó }\end{array}$

BRIDG speech 3SG.REFL ANAPH 3SG.PST be God near

'[In the beginning there was the word, lit. speech.] That speech was near God.' $[\mathrm{MOC}]^{3}$

introduced in Semitic linguistic (Creissels \& Good 2018). Construct forms are used in Mano as heads of noun phrases with certain types of dependents, excluding possessors, but including nominal or verbal attributes.

${ }^{3}$ In (14), the $a ̀$ marker is ambiguous between its function as a possessor ('his speech') and an anaphoric marker ('that speech'), but, given the context, I pick the latter function to define its use here. 


\section{Situated definiteness markers in other South Mande languages}

As mentioned in the introduction, some other South Mande languages have prenominal determiners having as their grammaticalization source the $3 \mathrm{sg}$ pronoun. These languages are: Kla-Dan, Dan-Gweetaa, Tura, Gban, and Guro. In most cases, the authors working on these languages do not give these markers a separate gloss, and I adopt their usage. The following examples serve to illustrate some interesting uses of determiners in these languages from the point of view of their semantics or syntax but do not give an exhaustive account. In the remaining South Mande languages, Beng, Mwan, Wan and Yaure, all determiners and articles are postnominal.

Example (15) from Kla-Dan illustrates the use of referents (young men and children) introduced by the pronoun à in the determiner function as first mentions. Their identity can easily be calculated, as they are represented as typical inhabitants of a village, a setting under discussion in the story. The pronoun is also frequently used in the anaphoric function, for example, to mark the relativized noun phrase in the matrix clause (see Makeeva 2012: 311).

(15) Kla-Dan (Makeeva, p.c.)

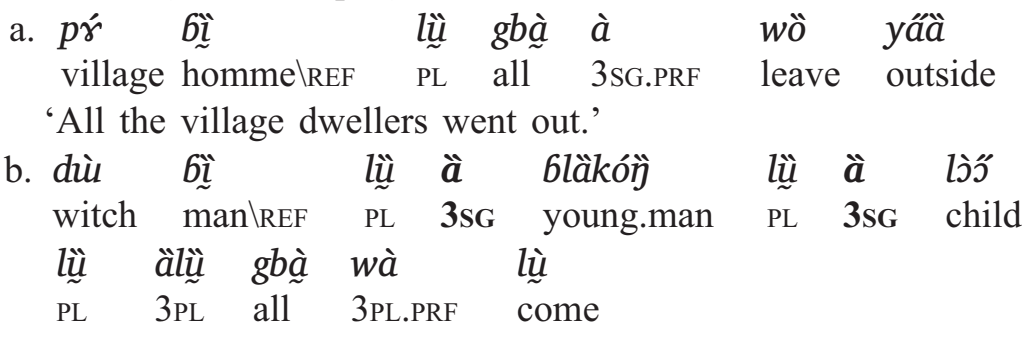

'The witches, the young men, the children, all of them came.'

In Dan-Gweetaa, the à marker has a syntactic distribution very similar to the one in Mano: in particular, it can be used with proper nouns (16) and with relational nouns accompanied by their inalienable possessors (17). 
(16) Dan-Gweetaa (Vydrin 2017a: 508)

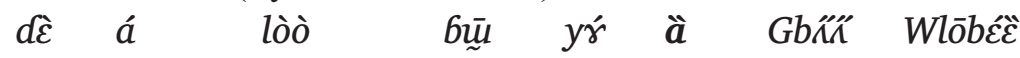
that 1SG.JNT come:JNT there SEQ 3SG Gwee Robert '́- $\quad p \bar{\gamma} . .$.

3SG.JNT-3SG Say:JNT

'When I came there, that Gwee Robert said...'

(17) Dan-Gweetaa (Vydrin 2017a: 508)

$\begin{array}{lllllll}\ldots \dot{\gamma} & k \ddot{n} & p \dot{\gamma} & a ̀ & \bar{\eta} & \text { dòò } & \text { Kèsê }\end{array}$

3SG.JNT do:JNT too 3sG 1sG elder.brother Kese

Wlōbéč $\quad 6 a ̈ \quad d e ̄ b \dddot{~} \quad k a ́$

Robert poss woman with

'She is also the wife of that elder brother of mine, Kese Robert.'

In Tura, examples include à sê̂ikwế 'precisely this book' (Idiatov $\&$ Aplonova 2017: 605). In Gban, the preposed 3sg pronoun optionally accompanies a postnominal determiner.

(18) Gban (Fedotov 2017: 956)

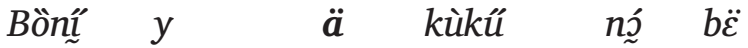

Spider 3SG.PST 3sg calebash this take.PST.PREH

'[The Spider's son advised him to move the calabash of wisdom from his stomach to his back, so that it would be easier for him to climb the papaya.] Then the Spider took this calabash of his.'

Finally, in Guro, the marker deriving from the 3sg pronoun is analyzed as a definite article. It is not used for first mentions in discourse (20). It can be used with relational nouns accompanied by their pronominal inalienable possessors, but also with pronominal direct objects (19), a use which I have not come across in other languages of the family.

(19) Guro (Kuznetsova \& Kuznetsova 2017: 796)

$\begin{array}{llll}\bar{a} & \grave{a} & \bar{\imath} & 6 \bar{a} l a \bar{a} a\end{array}$

1SG.SBJ REF 2SG beat:PFV

'I beat you (finally, as I was intending to).' 
(20) Guro (Kuznetsova \& Kuznetsova 2017: 796)

$\underset{\sim}{a}(<a \mathfrak{a} a ̀) \quad b \bar{a} l \bar{e} \quad b \bar{a} l \bar{a}-\bar{a}$

1SG.IPFV:REF dog beat-IPFV

'I will beat that (aforementioned; *this here) dog.'

In Kla-Dan, Dan-Gweetaa, Tura and Guro the head noun used with the marker in question can sometimes be used in the low-tone form (glossed as an izafet form in Dan-Gweetaa and Tura, as a referential status form in Kla-Dan, and as a generic form in Guro). See in KlaDan the noun $p \grave{\lambda}$ 'thing' used in its lexical form and its extra-low tone when followed by the à marker:

(21) Kla-Dan (Makeeva 2012: 112)

\begin{tabular}{|c|c|c|c|c|c|c|c|}
\hline $\begin{array}{l}\text { Bàa á } \\
\text { 1 SG.PROSP }\end{array}$ & $\begin{array}{l}p \grave{i} \\
\text { thing }\end{array}$ & $\begin{array}{l}\text { bá } \\
\text { some }\end{array}$ & $\begin{array}{l}\text { gbällè } \\
\text { ask }\end{array}$ & $\begin{array}{l}\grave{r} \\
2 \mathrm{SG}\end{array}$ & $\begin{array}{l}\text { gö, } \\
\text { PP }\end{array}$ & $\begin{array}{l}\dddot{a} \\
3 \mathrm{SG}\end{array}$ & $\begin{array}{l}p \grave{n} \\
\text { thing } \backslash \text { REF }\end{array}$ \\
\hline & dè & bry" & $\begin{array}{l}y a ̀ ~ \\
3 \text { SSG.PRF }\end{array}$ & $\begin{array}{l}62 \\
\text { enter }\end{array}$ & $\begin{array}{l}\grave{\eta} \\
1 \mathrm{SG}\end{array}$ & $\begin{array}{l}\text { gú } \\
\text { in }\end{array}$ & \\
\hline
\end{tabular}

In (22) from Dan-Gweetaa, the noun diā̄̄ 'speech' is used in its izafet form.

(22) Dan-Gweetaa (Vydrin 2017a: 549)
Gbätò dĩ $\dot{\gamma}$
dùà,
$y$ '̊ $^{\prime \prime} \mathbf{i}^{\prime}$
Gbato FOC REL.3SG.JNT run.away:JNT SEQ 1PL.EXCL.JNT-3SG
diää $z \bar{\Lambda}-s \bar{\imath} \bar{\Lambda}$
speech:IZF kill-DUR
'It was Gbato who ran away, and we are discussing it (lit.: killing that speech).'

Similar examples are also attested in Tura and Guro (Idiatov, p.c., O. Kuznetsova, p.c.). In contrast, Gban does not have a similar head marking morphology (Fedotov, p.c.). Finally, the Goo language, closely related to Tura, has izafet marking and a 3 sg pronoun used as a determiner, 
but whether or not it is used with $3 \mathrm{sg}$ pronoun is not clear (Aplonova, p.c.). Table 1 summarizes information on those South Mande languages where the $3 \mathrm{sg}$ pronoun developed determiner functions and those which have low tone nominal head marking, including the marking used with the determiner in question.

Table 1

3sg pronoun used as a determiner

in South Mande (Vydrin et al. 2017)

\begin{tabular}{|l|c|c|c|}
\hline & $\begin{array}{c}\text { 3sg used } \\
\text { as a } \\
\text { determiner }\end{array}$ & $\begin{array}{c}\text { tonal nominal } \\
\text { head marking }\end{array}$ & $\begin{array}{c}\text { tonal nominal head } \\
\text { marking with 3sg used } \\
\text { as a determiner }\end{array}$ \\
\hline Mwan & - & - & - \\
\hline Yaure & - & - & - \\
\hline Wan & - & - & - \\
\hline Beng & - & - & - \\
\hline Gban & + & - & $?$ \\
\hline Goo & + & + & + \\
\hline Guro & + & + & + \\
\hline Tura & + & + & + \\
\hline Dan-Gweetaa & + & + & + \\
\hline Kla-Dan & + & + & + \\
\hline Mano & + & + & \\
\hline
\end{tabular}

As we can see from Table 1, Tura, Dan-Gweetaa, Kla-Dan, Guro and Mano exhibit the same cluster of morphosyntactic features: they all have a $3 \mathrm{sg}$ pronoun used as a determiner and tonal nominal head marking, which can be used with the aforementioned determiner. While Gban has a similar determiner, it does not have tonal nominal head marking. 


\section{Definite article in Kpelle and the contact hypothesis}

The fact that five South Mande languages exhibit a common set of properties could be explained by the genealogical factor. Yet Mano stands somewhat apart: while in all five languages the tonal head marking is optional, in Mano it is used somewhat more frequently than in the other four languages. While the exact corpus counts are not available, in Guro, the low-tone form is found in approximately one in twenty uses (O. Kuznetsova, p.c.), in Kla-Dan, in one in thirteen uses (Makeeva, p.c.). In Mano, the low-tone form occurred in 10 examples among 58 in a corpus selection, or about one in six uses. ${ }^{4}$ In this section, I suggest that it is the contact with Kpelle that affects the frequency of use of the low-tone form in combination with the à marker.

Kpelle is a Southwest Mande language in intense contact with Mano. It has a prenomial article expressed by a tonal prefix whose underlying form is $\grave{\eta}$ - and which triggers consonant alternation; all examples are taken from Konoshenko (2017). Crucially, at the morphonological level the article triggers obligatory tonal lowering, see: héléý 'trap' vs. zèléý /ìhéléń/ ‘(this) trap'; béláá ‘sheep' vs. mèláá /ỳbéláá/ '(this) sheep' (ex. (24)).

The fact that the determiner in Mano triggers tonal lowering on the head more often than in other South Mande languages could be explained by influence from Kpelle. Several additional considerations are in place. First of all, Mano is the only South Mande language in intense contact with Southwest Mande. Next, the Kpelle article is homonymous and etymologically related to the 3 sg prefix in the language, so the matching in pattern is evident. Furthermore, it is not

${ }^{4}$ I counted only those instances where the lexical tone of the head noun was not low, so that there was a contrast between a lexical form and a low-tone form. In addition, I excluded borrowings and proper names which do not have contrasting forms, as well as complex nouns and noun phrases with preposed dependents, where the low tone on the head could be motivated by the presence of dependents, rather than the à marker. 
the only morphonological operation in Mano that is attributable to contact with Kpelle: another one is consonant alternation in Guinean Mano varieties which affects a much broader set of consonants, presumably under the influence from Kpelle (Khachaturyan 2018). Next, only very few morphonological effects of contact in the opposite direction (from Mano or, broader, South Mande to Kpelle) have been attested: one known example is the borrowing of the reciprocal marker. Finally, at least some other Southwest Mande languages have similar prefixed articles; on Looma, see Mischenko (2017), on Loko, see Vydrin \& Morozova (2017). Neither of these languages is in contact with South Mande languages and could be directly influenced by them, which make it unlikely that Mano was the source of the construction in question in Southwest Mande.

An additional argument in favor of the Kpelle influence on Mano in the frequency of the tonal lowering on the head is that it occurs even more often in areas with the most widespread bilingualism. My corpus contains recordings from residents of (quasi-) monolingual villages, Beleton and Kpala, in the Bounouma district as well as from residents of multilingual urban settings, N'zérékoré and Diécké. While the former used the low-tone form in 2 instances and did not use it in 19 other (low tone was used in 10\% of cases), the latter used it more frequently, in 8 instances and did not use it in 29 other (low tone was used in about $20 \%$ of cases). ${ }^{5}$ This result has to yet be compared with the use of low-tone forms in other nominal constructions. It should also be noted that the most bilingual, so to speak, adult speaker in my sample, whose mother was a Mano speaker and whose father was

${ }^{5}$ The result is not statistically significant under the Fisher exact test. One issue is the small size of the monolingual sample: had the sample of monolingual speech been four times bigger with the same proportion of low tone, the result would have been significant. Another issue is that the linguistic background of monolinguals was assessed only approximately: residents of monolingual villages may be competent in Kpelle. However, it is very unlikely that Mano speakers residing in multilingual urban settings do not speak Kpelle, see Khachaturyan \& Konoshenko (accepted). 
a Kpelle speaker and who grew up in a bilingual village, used the lexical form in a context where my primary language consultant, a Mano speaker whose parents are from a monolingual village, would prefer the low-tone form, kèlè 'shed:CSTR' instead of kélé 'shed' (23). So the use of the low-tone form is definitely a tendency, not a rule, and requires further investigation.

\section{(23) $k \bar{a} \quad s \hat{\varepsilon} k \bar{\varepsilon} \grave{\varepsilon} \quad \grave{a} \quad k e ́ l e ́ ~ d \bar{\jmath} \quad p \grave{\varepsilon} l \grave{\varepsilon}$ \\ 2PL thank.you BRIDG shed build place:CSTR \\ 'Thank you for building that shed.' [MOC]}

While there is possibly some convergence in the form of the definite constructions in South Mande and Kpelle (determiner deriving from a $3 \mathrm{sg}$ pronoun + noun in a low tone form), there is a clear difference. First of all, the exact phonological details of low tone assignment in Kpelle and in South Mande languages are radically different. In particular, while in South Mande languages the low tone affects the entire metrical foot (cf. in Mano, kélé 'shed'; kèlè 'shed:CSTR'), in Kpelle it affects just the first syllable (hélén 'trap' vs. zèléń /j̀h '(this) trap').

Next, the tonal change resulting from the article affixation in Kpelle affects the first word of the noun phrase, which may not be the head. In (24), it is the noun béláá 'sheep' that receives low tone on the first syllable and undergoes consonant alternation, while the head is the noun káxó 'leg'.

(24) Kpelle (Konoshenko, p.c.)

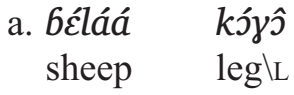
'(a) sheep leg'
b. mèláá kó
DEF \sheep leg\L
'the sheep leg'


In Mano, if the head of the NP is adjacent to à, it may or may not acquire the low tone; but if the head is not adjacent to $\grave{a}$, it never acquires the low tone because of $\grave{a}$, and neither does the non-head word which happened to be adjacent to $\grave{a}$ in this case. In (25), the noun $y \bar{\jmath}$ 'wine' is adjacent to the determiner $a$ but is used in its lexical form. The head, $\eta w$ ' 'problem', is used in the low-tone form, which, however, is due to the presence of the dependent $y \bar{\jmath}$ and would have been used even in the absence of the determiner $\grave{a}$.

\section{(25) $\grave{a} \quad y \bar{\jmath} \quad$ jwò $\quad w \bar{\varepsilon}$ tó mōý $g b \bar{a} \bar{a}$ kílí \\ BRIDG wine problem:CSTR DEM1 leave well now this.way \\ 'Leave the wine matter like this.' [MOC]}

As example (25) illustrates, the low-tone Mano form and its equivalents in Dan and Tura forms are also used in a variety of contexts of nominal modification and could be analyzed as construct forms (Creissels \& Good 2018). Similar tonal head marking exists in Kpelle, but has a narrower range of distribution and involves a tonal replacement operation which is formally different both from the tonal change resulting from the adjunction of the definite article and from the rules of formation of construct forms in South Mande, since, in addition to low tone head marking, it involves spreading of the high tone from the preposed dependent (Konoshenko 2014). In example (24) above, the head noun kśý 'leg', the head of a noun phrase with a nonreferential attributive dependent, receives low tone marking and is also affected by the spread of the high tone from béláá 'sheep', which results in the surface H-HL tonal pattern of the head noun ( $k$ ófô leg $\backslash \mathrm{L}$ ).

More importantly still, the distributional patterns of the determiners in Mano (and, very probably, other South Mande) and in Kpelle are clearly distinct. The Kpelle article is used to mark definiteness and does not occur with non-referential and indefinite NPs; in particular, it cannot co-occur with the indefinite determiner tă within the same NP, so uses like in (11) in Mano are ungrammatical. 
(26) Kpelle (Konoshenko 2017: 315)

\begin{tabular}{|c|c|c|}
\hline $\begin{array}{l}\text { クé } \\
\text { 1SG.BASE }\end{array}$ & $\begin{array}{ll}\text { 6òlǔ } & \text { tă } \\
\text { goat } & \mathrm{INDF}\end{array}$ & $\begin{array}{ll}\text { kàà } & \text { dàă } \\
\text { see } & \text { DEFlvillage }\end{array}$ \\
\hline
\end{tabular}

The article cannot occur in possessive noun phrases where the nouns are accompanied by their pronominal (in)alienable possessors as it cannot attach to the left of a pronoun or a pronominal prefix, in contrast with Mano (12), Dan-Gweetaa (17) or Guro (19).

In addition, I have at my disposal a short corpus of parallel oral translations from a written Kpelle source into Mano. It turns out that none of the examples of the use of the definite prefix, including the most apparent ones involving an evident consonant alternation of the noun to which the prefix is attached, corresponded to the use of the à marker in Mano. It corresponded either to nothing at all (27) or to a postnominal demonstrative $y \bar{a}$, kílía or kílíw $\bar{\varepsilon}$, as in (28). Likewise, the Mano determiner did not always correspond to the Kpelle determiner.

(27) a. Mano

$\begin{array}{lll}\text { tò̀̀ } & v \grave{j} & \text { pié } \\ \text { mountain } & \mathrm{PL} & \text { at }\end{array}$

b. Kpelle
nyéegha
$n w u \hat{o}^{6}$
DEF $\backslash$ mountain-PL head.LOC
'on the mountains'

(28) a. Mano

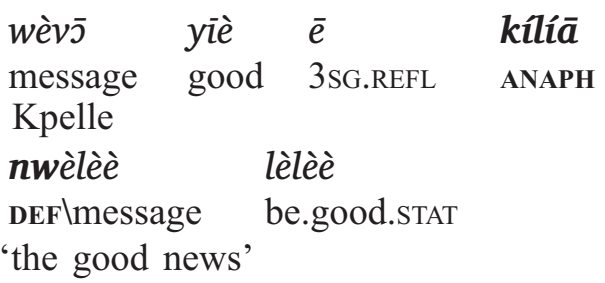

${ }^{6}$ The Kpelle examples are given in the orthographic notation. 
Thus, the differences in distribution of the definiteness markers in South and Southwest Mande languages suggest that the use of the 3sg pronoun for marking definiteness is an independent innovation in these two branches of Mande. In all these languages there is a possibility of tonal marking of the head directly following the marker, while in Southwest Mande such tonal head marking is obligatory. Yet the fact that in Mano, the South Mande language in most intense contact with Southwest Mande - and in particular, with Kpelle - the tonal marking is used more frequently than in other South Mande languages, and especially so in the idiolects of individuals residing in areas of widespread bilingualism, suggests that contact and bilingualism could increase the frequency of use of the low tone.

\section{Discussion and conclusion}

In this article, I reviewed the basic semantic functions of the determiner $\grave{a}$ in Mano, which is used to mark "situated definiteness" (Vydrin 2017a): most prominently, bridging and anaphora. The marker derives from the 3 sg pronoun. Similar markers are also used in a number of other South Mande languages, including Kla-Dan, Dan-Gweetaa, Tura, Guro and Gban, and in all but Gban the head noun can take a low-tone head marking. In Mano, low-tone head marking is used more frequently than in other South Mande languages. I argued that the increased frequency of use of such marking could be influenced by contact with the Southwest Mande language Kpelle, which has a grammaticalized preposed definiteness marker, also deriving from a 3 sg prefix and triggering low tone on the noun it attaches to. Thus, Mano can be characterized as being caught in the crossfire between intragenetic group factors determining the specific patterns of the use of the prenominal determiner derived from a 3 sg pronoun, and contact influence from Kpelle at the level of phonology with an increased frequency of grammatical low tone. For the discussion of contact effects analyzed through the lens of variation and differences in frequency, see Torres Cacoullos \& Travis (2018). Curiously, in the two language groups the 
distribution of the two constructions is markedly distinct, and even in Mano the construction retains its patterns of distribution, which is manifest in parallel translations from Kpelle into Mano.

Another, perhaps stronger contact scenario could be not statistical (increased frequency of an existing option), but rather categorical: the emergence of a new option. In that scenario, the use of the low-tone form in the Mano construction with a preposed determiner deriving from a $3 \mathrm{sg}$ pronoun appeared in Mano under the influence of Kpelle. Its occurrence in other Southern Mande languages, Dan, Tura and Guro, could then be explained by further contact between these languages, which are not at all or in much less intense direct contact with Kpelle. It would then explain why the use of low tone in these languages is less widespread and is not mentioned in the grammar sketches.

I argue for a similar process of gradual diffusion of contact influence in the case of the inclusory constructions with dedicated inclusory pronouns (Khachaturyan 2019). These pronouns are found in Kpelle along with other Southwestern Mande languages, but also in Mano, very likely under the Kpelle influence, and in Dan-Gweetaa, probably under the influence of Kpelle and/or of Mano. While in Mano, the pronouns are likely borrowed from Kpelle, in Dan-Gweetaa the lexical material is original, but the fusion process leading to the emergence of a separate pronominal series could be triggered by contact. These pronouns are not found in other Southern Mande languages, including closely related ones, such as Kla-Dan and Tura. Thus, in the case of the determiner triggering the use of low-tone head marking, we could deal with a slightly larger convergence zone, including this time KlaDan, Guro and Tura, with the same underlying mechanism of spread of contact effect.

In both scenarios, the influence of Kpelle on Mano represents an interesting case in language contact. It is a delicate combination of matter and pattern borrowing (Matras \& Sakel 2007). To begin with, the constructions in all the languages involved have the same basic structure: a marker derived from a 3 sg pronominal marker followed by the head noun or an NP. At that level, no pattern is borrowed. What 
is imported instead is matter: the use of low tone on the head noun. However, such tonal operation is not unknown in the recipient language(s) either, which recur to low-tone head marking (construct form) in a variety of noun phrases (Creissels \& Good 2018). This form can arguably be reconstructed at the level of proto-Mande (Vydrin 2017b: 34). What can be attributed to contact is thus rather restricted: the Kpelle construction with the low tone "inspired" the recipient language(s) to use the already available low-tone form in a new context with the determiner (scenario 2) or, if such uses were already available, to increase their frequency (scenario 1).

The final concluding remark concerns the functions of the à marker in Mano, which is used for bridging, anaphora and with some contextually identifiable referents. While dedicated anaphoric markers have been attested cross-linguistically (such as in Komnzo, a Yam language of Papua New Guinea, Döhler 2018), this particular clustering of functions which excludes, for example, contextually unique (the night, as in ex. (9)), absolutely unique (the moon) or establishing referents (referents whose identity is established, for example, by a relative clause), appears to be rather rare: a possible parallel could be Akan, a Kwa language (Becker 2019). Thus, the Mano marker à could be an interesting addition to the typology of definiteness markers.

\section{Acknowledgements}

This article would not have been written if Valentin Feodos'evich Vydrin had not taken me on a Mande adventure eleven years ago. I am immensely grateful for his continuous inspiration and for the journey we have made together. I greatly appreciate Maria Konoshenko's collaboration in the analysis of the parallel Mano - Kpelle corpus. The joint project was supported by a grant from the Academy of Finland, project number 323403. I also thank Dmitry Idiatov, Katja Aplonova, Nadja Makeeva, Olga Kuznetsova and Maxim Fedotov for the additional information they provided on Tura, Goo, Kla-Dan, Guro and Gban, respectively. This article about contact between languages is driven 
by contact between researchers, which was established thanks to Valentin and the collegiality he fosters among his students in the field and beyond. As usual, my thanks go to Pe Mamy, my invaluable language consultant, and to the anonymous reviewers for their useful comments. I appreciate Mark Shackleton's help with language revision. Mano data are taken from my field materials collected with the help of various supporting institutions, most recently, the University of Helsinki.

\section{Abbreviations}

$\begin{array}{lll}\text { ADR }- \text { addressee } & \text { EXI }- \text { existential } & \text { POSS }- \text { possessive } \\ \text { ANAPH }- \text { anaphoric } & \text { FOC }- \text { focus } & \text { PP }- \text { postposition } \\ \text { ASSOC }- \text { associative } & \text { FR }- \text { French } & \text { PREH }- \text { prehordienal } \\ & \quad \text { source of borrowings) } & \\ \text { BASE }- \text { basic form } & \text { GER }- \text { gerund } & \text { PRF }- \text { perfect } \\ \text { BKGR }- \text { background } & \text { INDF } \text { - indefinite } & \text { PROSP }- \text { prospective } \\ \text { BRIDG }- \text { bridging } & \text { INF }- \text { infinitive } & \text { PST }- \text { past } \\ \text { COND }- \text { conditional } & \text { IPFV }- \text { imperfective } & \text { REF }- \text { referential } \\ \text { COP }- \text { copula } & \text { IZF }- \text { isafet } & \text { REFL }- \text { reflexive } \\ \text { CSTR }- \text { construct form } & \text { JNT }- \text { conjoint } & \text { REL }- \text { relative } \\ \text { DEF }- \text { definite } & \text { L }- \text { low tone } & \text { SBJ }- \text { subject } \\ \text { DEM }- \text { demonstrative } & \text { LOC }- \text { locative } & \text { SBJV }- \text { subjunctive } \\ \text { DUR }- \text { durative } & \text { NEG }- \text { negation } & \text { SEQ }- \text { sequential } \\ \text { EMPH }- \text { emphatic } & \text { PFV }- \text { perfective } & \text { SG }- \text { singular } \\ \text { EXCL }- \text { exclusive } & \text { PL }- \text { plural } & \text { STAT }- \text { stative }\end{array}$

\section{References}

Becker, Laura. 2019. Articles in the World's languages. Erlangen - Nuremberg: University of Erlangen - Nuremberg. (Ph.D. dissertation.)

Clark, Herbert H. 1975. Bridging. In Schank, Roger C. \& Nash-Webber, Bonnie L. (eds.), Theoretical issues in natural language processing, 169-174. New York: Association for Computing Machinery.

Creissels, Denis \& Good, Jeff. 2018. Current issues in African morphosyntactic typology. In Güldemann, Tom (ed.), The languages and linguistics of Africa, 709-881. Berlin: De Gruyter. (The World of Linguistics 11.) 
Döhler, Christian. 2018. A Grammar of Komnzo. Berlin: Language Science Press.

Fedotov, Maksim. 2017. Gban jazyk [The Gban language]. In Vydrin, Valentin \& Mazurova, Julia \& Kibrik, Andrej \& Markus, Elena (eds.), Jazyki mira: Jazyki mande [Languages of the World: Mande Languages], 902-999. St. Petersburg: Nestor-Istorija.

Idiatov, Dmitry \& Ekaterina Aplonova. 2017. Tura jazyk [The Tura language]. In Vydrin, Valentin \& Mazurova, Julia \& Kibrik, Andrej \& Markus, Elena (eds.), Jazyki mira: Jazyki mande [Languages of the World: Mande Languages], 583-616. St. Petersburg: Nestor- Istorija.

Khachaturyan, Maria. 2018. A Sketch of dialectal variation in Mano. Mandenkan 59. 31-56.

Khachaturyan, Maria. 2019. Inclusory pronouns in Mande: The emergence of a typological rarum. Folia Linguistica 53. 87-123.

Khachaturyan, Maria. 2020a. Common ground in demonstrative reference: The case of Mano (Mande). Frontiers in Psychology. 11:543549. (doi: 10.3389/fpsyg.2020.543549)

Khachaturyan, Maria. 2020b. A typological portrait of Mano, Southern Mande. Linguistic Typology. https://doi.org/10.1515/lingty-2020-2050. [Epub ahead of print].

Khachaturyan, Maria \& Maria Konoshenko. Accepted. Assessing (a)symmetry in multilingualism: The case of Mano and Kpelle in Guinea. International Journal of Bilingualism. (Special issue edited by Nina Dobrushina, Olesya Khanina \& Brigitte Packendorf.)

Konoshenko, Maria. 2014. The syntax of tone in Guinean Kpelle. In Leung, Herman, et al. (eds.), Proceedings of the Fortieth Annual Meeting of the Berkeley Linguistics Society, 233-252. Berkeley, CA: Berkeley Linguistics Society.

Konoshenko, Maria. 2017. Kpelle jazyk [The Kpelle language]. In Vydrin, Valentin \& Mazurova, Julia \& Kibrik, Andrej \& Markus, Elena (eds.), Jazyki mira: Jazyki mande [Languages of the World: Mande Languages], 284-343. Saint Petersburg: Nestor-Istorija.

Kuznetsova, Natalia \& Olga Kuznetsova. 2017. Guro jazyk [The Guro language]. In Vydrin, Valentin \& Mazurova, Julia \& Kibrik, Andrej \& Markus, Elena (eds.), Jazyki mira: Jazyki mande [Languages of the World: Mande Languages], 765-877. St. Petersburg: Nestor-Istorija. 
Makeeva, Nadezhda. 2012. Grammatičeskij stroj jazyka kla-dan v tipologičeskom kontekste rodstvennyx jazykov [The grammatical system of Kla-Dan in the typological context of related languages]. Moscow: Institute of Linguistics RAS. (Ph.D. dissertation.)

Matras, Yaron \& Jeanette Sakel. 2007. Investigating the mechanisms of pattern replication in language convergence. Studies in Language 31(4). 829-865.

Mischenko, Daria. 2017. Looma jazyk [The Looma language]. In Vydrin, Valentin \& Mazurova, Julia \& Kibrik, Andrej \& Markus, Elena (eds.), Jazyki mira: Jazyki mande [Languages of the World: Mande Languages], 343-414. Saint Petersburg: Nestor-Istorija.

Torres Cacoullos, Rena \& Travis, Catherine E. 2018. Bilingualism in the community: Code-switching and grammars in contact. Cambridge: Cambridge University Press.

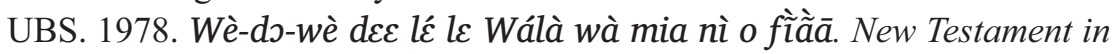
Mano. Translation by June M. Hobley Jackson \& Stanley Younguoi. Monrovia: The Bible Society in Liberia.

Vydrin, Valentin. 2017a. Dan jazyk [The Dan language]. In Vydrin, Valentin \& Mazurova, Julia \& Kibrik, Andrej \& Markus, Elena (eds.), Jazyki mira: Jazyki mande [Languages of the World: Mande Languages], 469582. Saint Petersburg: Nestor-Istorija.

Vydrin, Valentin. 2017b. Mande jazyki [Mande languages]. In Vydrin, Valentin \& Mazurova, Julia \& Kibrik, Andrej \& Markus, Elena (eds.), Jazyki mira: Jazyki mande [Languages of the World: Mande Languages], 16-45. St. Petersburg: Nestor-Istorija.

Vydrin, Valentin \& Morozova, Maria. 2017. Loko jazyk [The Loko language]. In Vydrin, Valentin \& Mazurova, Julia \& Kibrik, Andrej \& Markus, Elena (eds.), Jazyki mira: Jazyki mande [Languages of the World: Mande Languages], 414-456. Saint Petersburg: Nestor-Istorija.

Vydrin, Valentin \& Mazurova, Julia \& Kibrik, Andrej \& Markus, Elena (eds.). 2017. Jazyki mira: Jazyki mande [Languages of the World: Mande Languages]. Saint Petersburg: Nestor-Istorija.

Received 22.06.2020. Received in revised form 28.08.2020. Accepted 30.11.2020 